\title{
Atmospheric ammonia measurements in Houston, TX using an external-cavity quantum cascade laser-based sensor
}

\author{
L. Gong ${ }^{1}$, R. Lewicki ${ }^{2}$, R. J. Griffin ${ }^{1}$, J. H. Flynn ${ }^{3}$, B. L. Lefer ${ }^{3}$, and F. K. Tittel ${ }^{2}$ \\ ${ }^{1}$ Department of Civil and Environmental Engineering, Rice University, 6100 Main St., Houston, TX 77005, USA \\ ${ }^{2}$ Department of Electrical and Computer Engineering, Rice University, 6100 Main St., Houston, TX 77005, USA \\ ${ }^{3}$ Department of Earth and Atmospheric Sciences, University of Houston, 4800 Calhoun Rd., Houston, TX 77004, USA
}

Received: 3 May 2011 - Published in Atmos. Chem. Phys. Discuss.: 6 June 2011

Revised: 10 September 2011 - Accepted: 12 September 2011 - Published: 20 September 2011

\begin{abstract}
In order to improve the current understanding of the dynamics of ammonia $\left(\mathrm{NH}_{3}\right)$ in a major industrial and urban area, intensive measurements of atmospheric $\mathrm{NH}_{3}$ were conducted in Houston during two sampling periods (12 February 2010-1 March 2010 and 5 August 2010-25 September 2010). The measurements were performed with a 10.4- $\mu \mathrm{m}$ external cavity quantum cascade laser (EC-QCL)based sensor employing conventional photo-acoustic spectroscopy. The mixing ratio of $\mathrm{NH}_{3}$ ranged from 0.1 to $8.7 \mathrm{ppb}$ with a mean of $2.4 \pm 1.2 \mathrm{ppb}$ in winter and ranged from 0.2 to $27.1 \mathrm{ppb}$ with a mean of $3.1 \pm 2.9 \mathrm{ppb}$ in summer. The larger levels in summer probably are due to higher ambient temperature. A notable morning increase and a mid-day decrease were observed in the diurnal profile of $\mathrm{NH}_{3}$ mixing ratios. Motor vehicles were found to be major contributors to the elevated levels during morning rush hours in winter. However, changes in vehicular catalytic converter performance and other local or regional emission sources from different wind directions governed the behavior of $\mathrm{NH}_{3}$ during morning rush hours in summer. There was a large amount of variability, particularly in summer, with several episodes of elevated $\mathrm{NH}_{3}$ mixing ratios that could be linked to industrial facilities. A considerable discrepancy in $\mathrm{NH}_{3}$ mixing ratios existed between weekdays and weekends. This study suggests that $\mathrm{NH}_{3}$ mixing ratios in Houston occasionally exceeded previous modeling predictions when sporadic and substantial enhancements occurred, potentially causing profound effects on particulate matter formation and local air quality.
\end{abstract}

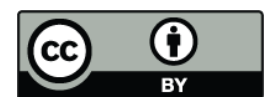

Correspondence to: L. Gong (lg15@rice.edu)

\section{Introduction}

As the third most abundant nitrogen-containing compound and predominant gaseous base in the atmosphere, ammonia $\left(\mathrm{NH}_{3}\right)$ plays an important role in atmospheric chemistry. It has many anthropogenic (e.g. agricultural crops, mineral fertilizers, and biomass burning) and natural (e.g. animals, oceans, and vegetation) sources in the environment. For rural and agricultural areas livestock remains the largest category in its emission inventory (Clarisse et al., 2009). However, in urban and more developed areas, industrial and motor vehicle activities contribute to significant increases in local or regional $\mathrm{NH}_{3}$ levels (Fraser and Cass, 1998; Kean and Harley, 2000; Kean et al., 2009; Hsieh and Chen, 2010).

Gaseous $\mathrm{NH}_{3}$ is normally present in the atmosphere at trace concentration levels ranging from parts per trillion to parts per billion (ppb). From a perspective of environmental concern, $\mathrm{NH}_{3}$ is a precursor of particulate matter (PM) because it can lead to the production of ammonium salts (e.g. $\left(\mathrm{NH}_{4}\right)_{2} \mathrm{SO}_{4}, \mathrm{NH}_{4} \mathrm{HSO}_{4}$, and $\left.\mathrm{NH}_{4} \mathrm{NO}_{3}\right)$ through chemical reactions with sulfuric and nitric acid formed by oxidation of sulfur dioxide and nitrogen oxides, respectively (Sutton et al., 2008). Formation of these salts may lead to homogeneous aerosol nucleation (McMurry et al., 2005). These secondary inorganic materials typically account for a large portion of fine particle mass (Malm, et al., 2004). Additionally, recent studies have shown that excess $\mathrm{NH}_{3}$ can provide sufficient aerosol alkalinity that gaseous nitrous acid will form particulate nitrite (Song et al., 2009). The resultant PM has significant implications for regional air quality, human health, atmospheric visibility, cloud formation, radiation budget, climate patterns, and nutrient cycling. Despite this, $\mathrm{NH}_{3}$ is not regulated under the National Ambient Air Quality Standards by the United States Environmental Protection Agency (EPA), which poses substantial difficulties and rigorous challenges to its emission reduction. Moreover, governmental air

Published by Copernicus Publications on behalf of the European Geosciences Union. 
quality monitoring network sites often do not regularly measure ambient $\mathrm{NH}_{3}$ concentrations.

Previous $\mathrm{NH}_{3}$ studies conducted near forests or agricultural areas with strong $\mathrm{NH}_{3}$ emission sources such as dairy operations, animal housing, livestock facilities, and slurry lagoons observed higher than average $\mathrm{NH}_{3}$ concentration levels (Aneja et al., 2001; Kawashima and Yonemura, 2001; Pryor et al., 2001; Mount et al., 2002; Ferm et al., 2005; Sarwar et al., 2005; Wilson and Serre, 2007; Rumburg et al., 2008; Clarisse et al., 2010). Relevant measurements performed at some urban sites in Europe, Asia, and North America indicate that the dynamics of $\mathrm{NH}_{3}$ mixing ratios are determined by many factors including meteorology, traffic patterns, gas-particle partitioning, and surface-atmosphere exchange (Brook et al., 1997; Bari et al., 2003; Lin et al., 2006; Nowak et al., 2006; Edgerton et al., 2007; Ianniello et al., 2010; Saylor et al., 2010).

Measurement of $\mathrm{NH}_{3}$ is difficult because it is readily converted to particulate ammonium and easily adsorbed onto surfaces. Traditional techniques employ passive samplers such as annular diffusion denuders with off-line analysis such as ion chromatography (Hoek et al., 1996; Burkhardt et al., 1998; Matsumoto and Okita, 1998; Erisman et al., 2001; Olszyna et al., 2005; Smith et al., 2007). Drawbacks of these methods often include low time resolution, poor sensitivity, and human-induced errors. Recently researchers have developed more sophisticated and reliable on-line $\mathrm{NH}_{3}$ sampling systems using chemical ionization mass spectrometry or laser spectroscopy with improved temporal resolution and detection limits (Fehsenfeld et al., 2002; Li et al., 2006; Nowak et al., 2007; Pogány et al., 2010).

Data regarding $\mathrm{NH}_{3}$ levels for the industrial and urban area of Greater Houston are still very limited. According to a photochemical model, the estimated $\mathrm{NH}_{3}$ mixing ratios for the Houston area are in the range of 1 to $15 \mathrm{ppb}$ (Pavlovic et al., 2006). The same study suggested $\mathrm{NH}_{3}$-rich conditions over southeast Texas. The only published study on $\mathrm{NH}_{3}$ measurements in Houston reported airborne observations below and above the planetary boundary layer (PBL) using a 14-day data set from aircraft measurements during the 2006 Texas Air Quality Study (Nowak et al., 2010). In that study, $\mathrm{NH}_{3}$ mixing ratios typically ranged from 0.2 to $3 \mathrm{ppb}$, but specific plumes with elevated $\mathrm{NH}_{3}$ levels ( 5 to $80 \mathrm{ppb}$ ) were related to point source emissions near the highly industrialized Houston Ship Channel (HSC). The $\mathrm{NH}_{3}$ enhancement was also coincident with a decrease in nitric acid $\left(\mathrm{HNO}_{3}\right)$ mixing ratios and an increase in particulate nitrate concentrations, indicating that ammonium nitrate was formed in these plumes. The paucity of data makes it crucial to improve the current understanding of the dynamics of $\mathrm{NH}_{3}$ in Houston and to further investigate the effects of $\mathrm{NH}_{3}$ on local and regional air quality. As a result, intensive $\mathrm{NH}_{3}$ measurements were made using a sensitive and selective 10.4- $\mu$ m external cavity quantum cascade laser (EC-QCL)-based sensor employing conventional photo-acoustic spectroscopy.

\section{Experimental methods}

\subsection{Instrument}

For the purpose of the $\mathrm{NH}_{3}$ environmental study a widely tunable EC-QCL, emitting a maximum optical power of $72 \mathrm{~mW}$ (Daylight Solutions Inc, Model 21106-MHF-001), was employed as a spectroscopic source. The single mode frequency output of the EC-QCL can be coarsely tuned from 933 to $1006 \mathrm{~cm}^{-1}$ with a minimum step size of $0.01 \mathrm{~cm}^{-1}$. In order to perform high resolution spectroscopy, a sinusoidal voltage, with a maximum amplitude of $100 \mathrm{~V}$, can be applied to the EC-QCL piezo element enabling mode hop free tuning within $\sim 1 \mathrm{~cm}^{-1}$. An amplitude modulated photo-acoustic spectroscopy (AM-PAS) technique was employed to monitor atmospheric $\mathrm{NH}_{3}$ at trace concentration levels. The stateof-the-art photo-acoustic detector used two balanced electret microphones placed in a $9.1-\mathrm{cm}$ differential resonant photoacoustic cell. The amplitude modulation of the laser beam was performed by a mechanical chopper wheel operating at $1.8 \mathrm{kHz}$ to match the resonance frequency of the photoacoustic cell at the selected working pressure of 220 Torr. The $\mathrm{NH}_{3}$ sensor architecture is depicted schematically in Fig. 1.

In order to improve and obtain a detection limit of single ppb levels required for sensitive atmospheric $\mathrm{NH}_{3}$ measurements, the optical beam was passed through the cell three times. A pyroelectric detector placed after a $10-\mathrm{cm}$ reference cell filled with $0.2 \%$ of $\mathrm{NH}_{3}$ at 30 Torr was used to compensate for possible EC-QCL wavelength drift, as well as to monitor its power. The pressure inside the system was kept at 220 Torr while the flow rate was maintained at $175 \mathrm{ml}$ min. In order to minimize $\mathrm{NH}_{3}$ adsorption onto surfaces and to prevent water vapor condensation in the sensor, the sensor enclosure was heated to $38^{\circ} \mathrm{C}$. All tubing was made of Teflon ${ }^{\circledR}$, and a particle filter was placed before the inlet to avoid undesirable contamination. In the present study, the $965.35 \mathrm{~cm}^{-1}$ absorption line of $\mathrm{NH}_{3}$ was chosen. This frequency was the optimal selection for the AM-PAS technique based on laser power, absorption strength, and minimized water vapor and carbon dioxide interferences. Under ambient conditions, these interferences were negligible compared to the signal from $\mathrm{NH}_{3}$.

For the sensor calibration, a certified mixture of 5 parts per million (ppm) of $\mathrm{NH}_{3}$ in nitrogen was used. To determine atmospheric concentration levels of $\mathrm{NH}_{3}$, each acquired sample scan was compared with the $5 \mathrm{ppm} \mathrm{NH}$ reference scan by implementing a LabView-based general least-square (LS) linear fitting algorithm. The linear LS procedure yields a fit coefficient value, which generally indicates to what extent each sample scan represents a reference scan. If the coefficient is equal to one, the $\mathrm{NH}_{3}$ mixing ratios for both reference and sample scans are identical. However, the linear fitting algorithm does not take into account the minimum detection limit of the sensor which was obtained after performing the 


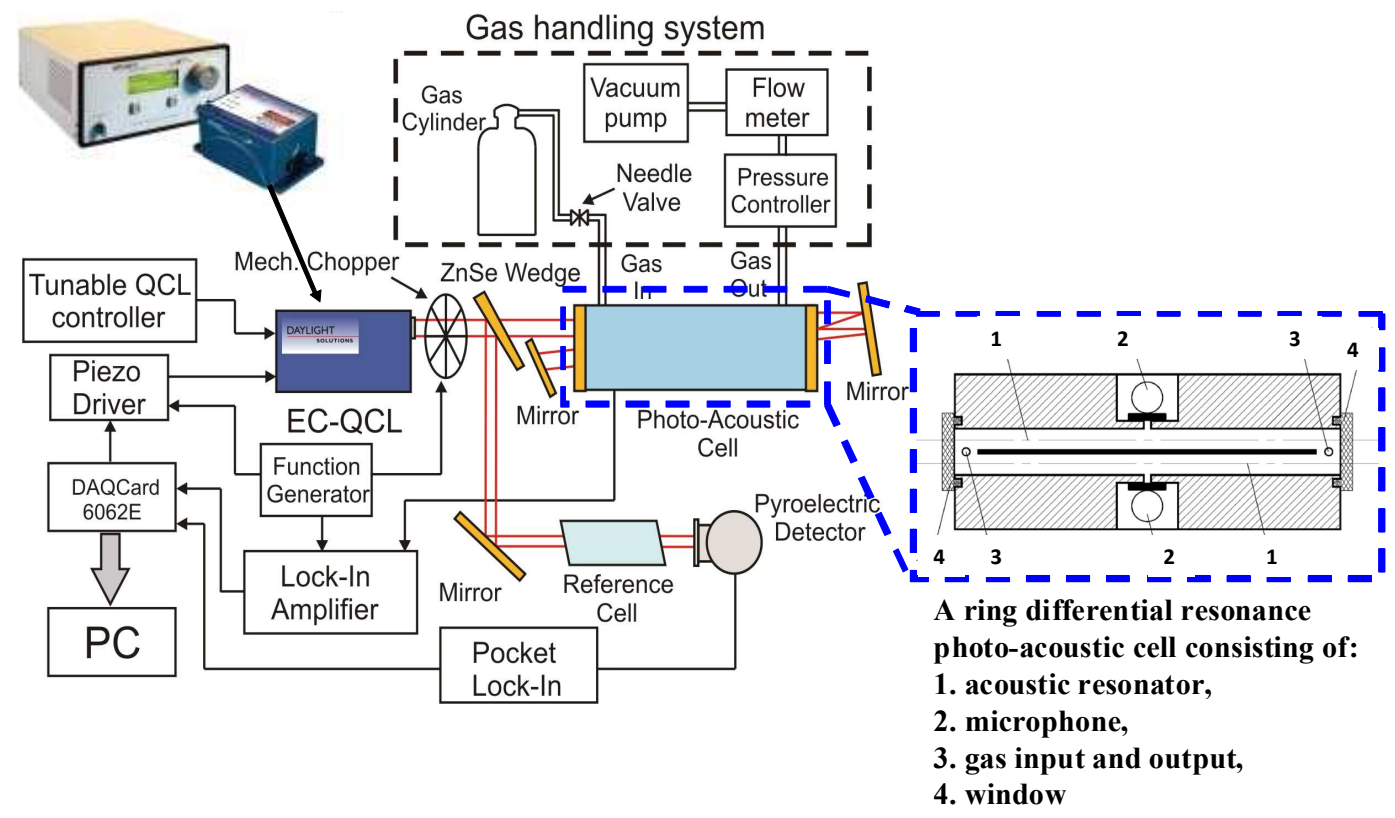

Fig. 1. The mid-infrared AM-PAS-based sensor platform for atmospheric $\mathrm{NH}_{3}$ detection used in this study.

Allan variance analysis. Therefore, an error/uncertainty of $0.72 \mathrm{ppb}$ acquired after averaging the data over $300 \mathrm{~s}$ needs to be included in the calculation of atmospheric $\mathrm{NH}_{3}$ levels. Meanwhile, pure nitrogen was used to obtain related spectral data for the zero line.

Field tests demonstrated that the time response of the $\mathrm{NH}_{3}$ sensor was on the order of seconds to one minute, which is sufficient to capture plumes during environmental measurements, and no $\mathrm{NH}_{3}$ losses were observed according to the detected signals when a standard of $5 \mathrm{ppm} \mathrm{NH}$ was employed. Big events usually last less than one hour. For example, after putting fingers close to the sensor inlet as a test, $\mathrm{NH}_{3}$ mixing ratios are rapidly elevated to $\sim 30 \mathrm{ppb}$, which is related to the $\mathrm{NH}_{3}$ generation from human skin. The subsequent decay to the baseline takes $\sim 30$ min according to a $90 \%$ recovery from the peak signal. In addition, the majority of the sampling inlet was heated using autotransformators and was made as short as possible to minimize the sites for $\mathrm{NH}_{3}$ to stick.

To investigate the long-term stability of the $\mathrm{NH}_{3}$ sensor, a set of data was acquired in the laboratory while pure nitrogen was flushed through the sensor photo-acoustic cell and an Allan deviation analysis, defined as the square root of the Allan variance, was performed. The results of this analysis show that the $\mathrm{NH}_{3}$ detection limit can be obtained at subppb concentration levels when the acquired data points are averaged for $1000 \mathrm{~s}$. For environmental monitoring purposes, where sensor time response is not a critical parameter, a long data averaging time is usually beneficial for the improvement of measurement accuracy because some noise sources can be removed by the averaging process. The minimum detection limit of the $\mathrm{NH}_{3}$ sensor used for real-time measurements in the field was $3.4 \mathrm{ppb}$ for a five-second acquisition time. The Allan deviation plot flattens out approximately after $300 \mathrm{~s}$. Therefore an averaging time of $5 \mathrm{~min}$ is the optimal selection in terms of the measurement accuracy. $\mathrm{A} \mathrm{NH}_{3}$ concentration level detection limit of $0.72 \mathrm{ppb}$ was achieved after averaging the data over $300 \mathrm{~s}$.

\subsection{Sampling site}

The $\mathrm{NH}_{3}$ sensor was deployed in a trailer atop an 18-story ( $\sim 65 \mathrm{~m}$ above ground level) building (North Moody Tower) located on the University of Houston (UH) main campus. This spot was selected because it is affected by many local point, line, and area emission sources from almost all wind directions. The site is considered highly urban without agricultural activities. It is $\sim 2.5$ miles southeast of downtown Houston and $\sim 7$ miles southwest of the HSC. The laser system was capable of unattended operation with continuous data acquisition for extended periods of time. Remote access enabled the real-time monitoring of the sensor performance. Meteorological parameters (e.g. temperature and relative humidity) as well as mixing ratios of other important air pollutants (e.g. oxides of nitrogen $\left(\mathrm{NO}_{\mathrm{x}}\right)$, total reactive nitrogen species $\left(\mathrm{NO}_{\mathrm{y}}\right)$, carbon monoxide $(\mathrm{CO})$, and sulfur dioxide $\left.\left(\mathrm{SO}_{2}\right)\right)$ are measured routinely by the $\mathrm{UH}$ research group at this location (Day et al., 2010; Lefer and Rappenglück, 2010; Lefer et al., 2010; Luke et al., 2010). Information regarding measurement techniques is provided in Table 1. 


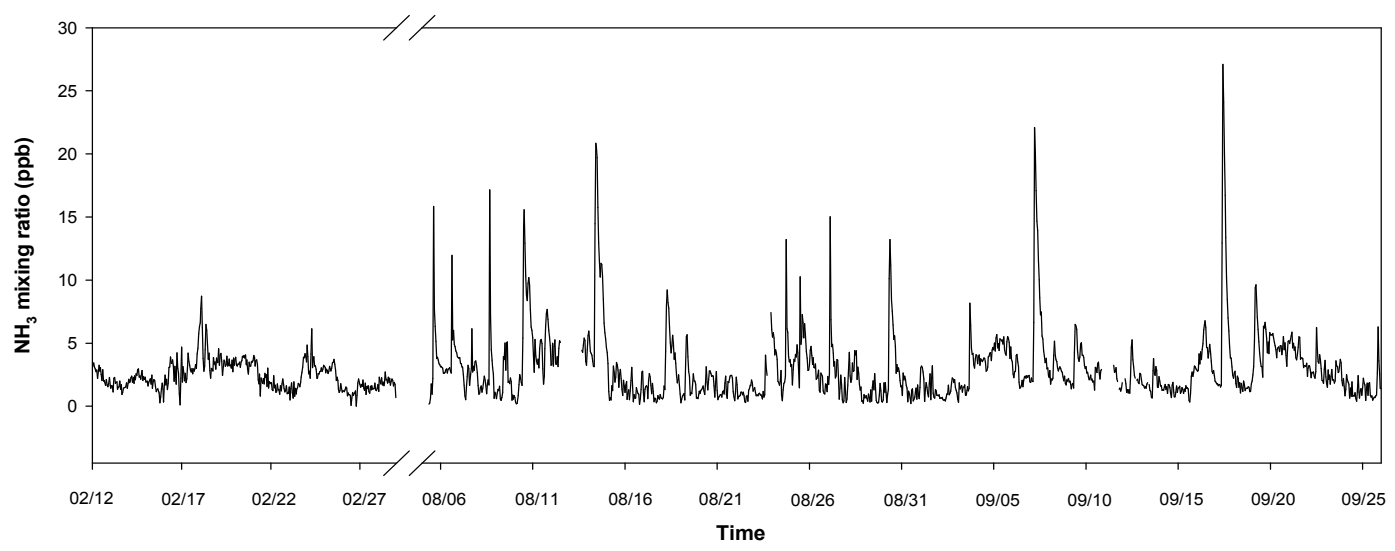

Fig. 2. A time series of $\mathrm{NH}_{3}$ mixing ratios measured using an EC-QCL-based sensor atop the North Moody Tower in Houston, TX during the two sampling periods. Notable increases in the $\mathrm{NH}_{3}$ mixing ratio are associated with transport from a coal-fired power plant, a chemical fire on an adjacent highway as a result of a crash of a tanker carrying agricultural chemicals, transport from the heavily industrialized HSC, and transport from the Gulf of Mexico during Hurricane Hermine.

Table 1. Measurement techniques for air pollutants and meteorological parameters.

\begin{tabular}{ll}
\hline Parameter & Measurement technique \\
\hline Temperature & Campbell Scientific HMP45C Platinum Resistance Thermometer \\
Relative humidity & Campbell Scientific HMP45C Humicap ${ }^{\circledR}$ 180 Capacitive Relative Humidity Sensor \\
Wind speed & Campbell Scientific 05103 R. M. Young Wind Monitor \\
Wind direction & Campbell Scientific 05103 R. M. Young Wind Monitor \\
$\mathrm{NO}_{\mathrm{x}}$ & Thermo Electron Corp. 42C Trace Level NO-NO $\mathrm{NO}_{\mathrm{x}}$ Analyzer (Chemiluminescence) \\
$\mathrm{NO}_{\mathrm{y}}$ & Thermo Electron Corp. 42C-Y NO Analyzer (Molybdenum Converter) \\
$\mathrm{CO}$ & Thermo Electron Corp. 48C Trace Level CO Analyzer (Gas Filter Correlation) \\
$\mathrm{SO}$ & Thermo Electron Corp. 43C Trace Level $\mathrm{SO}_{2}$ Analyzer (Pulsed Fluorescence) \\
$\mathrm{PBL}_{2}$ height & Vaisala DigiCORA Tethersonde System \\
\hline
\end{tabular}

Table 2. Statistics of $\mathrm{NH}_{3}$ data collected during the two sampling periods ( $<\mathrm{DL}$ indicates numbers below the detection limit).

\begin{tabular}{lcc}
\hline & \multicolumn{2}{c}{$\mathrm{NH}_{3}$ mixing ratio $(\mathrm{ppb})$} \\
\cline { 2 - 3 } & Winter & Summer \\
\hline Mean & 2.42 & 3.07 \\
Standard deviation & 1.16 & 2.87 \\
Maximum & 8.72 & 27.10 \\
Minimum & $0.10(<\mathrm{DL})$ & $0.16(<\mathrm{DL})$ \\
Median & 2.21 & 2.37 \\
10th Percentile & 1.16 & 0.73 \\
25th Percentile & 1.59 & 1.35 \\
75th Percentile & 3.17 & 3.89 \\
90th Percentile & 3.80 & 5.55 \\
\hline
\end{tabular}

\section{Results and discussion}

\subsection{Seasonal variation}

As mentioned above, measurements were conducted in both winter and summer. Figure 2 presents a time series of hourlyaveraged $\mathrm{NH}_{3}$ mixing ratios during two sampling periods (12 February 2010-1 March 2010 and 5 August 2010-25 September 2010) and indicates a large amount of variability and several episodes of elevated $\mathrm{NH}_{3}$ levels. The statistics of the two data sets are listed in Table 2.

Mixing ratios of $\mathrm{NH}_{3}$ were elevated in summer (mean of $3.1 \pm 2.9 \mathrm{ppb}$ ) compared to winter (mean of $2.4 \pm 1.2 \mathrm{ppb}$ ) leading to an inference that ambient temperature has a strong effect on $\mathrm{NH}_{3}$ levels. The average temperatures during the winter and summer sampling periods were $9.5 \pm 2.2^{\circ} \mathrm{C}$ and $28.7 \pm 1.9^{\circ} \mathrm{C}$, respectively. This observation agrees well with previous studies that found that temperature-dependent sources and/or processes affected seasonal variations of $\mathrm{NH}_{3}$ concentrations (Yamamoto et al., 1995; Lee et al., 1999; Aneja et al., 2000; Robarge et al., 2002; Lin et al., 2006; 

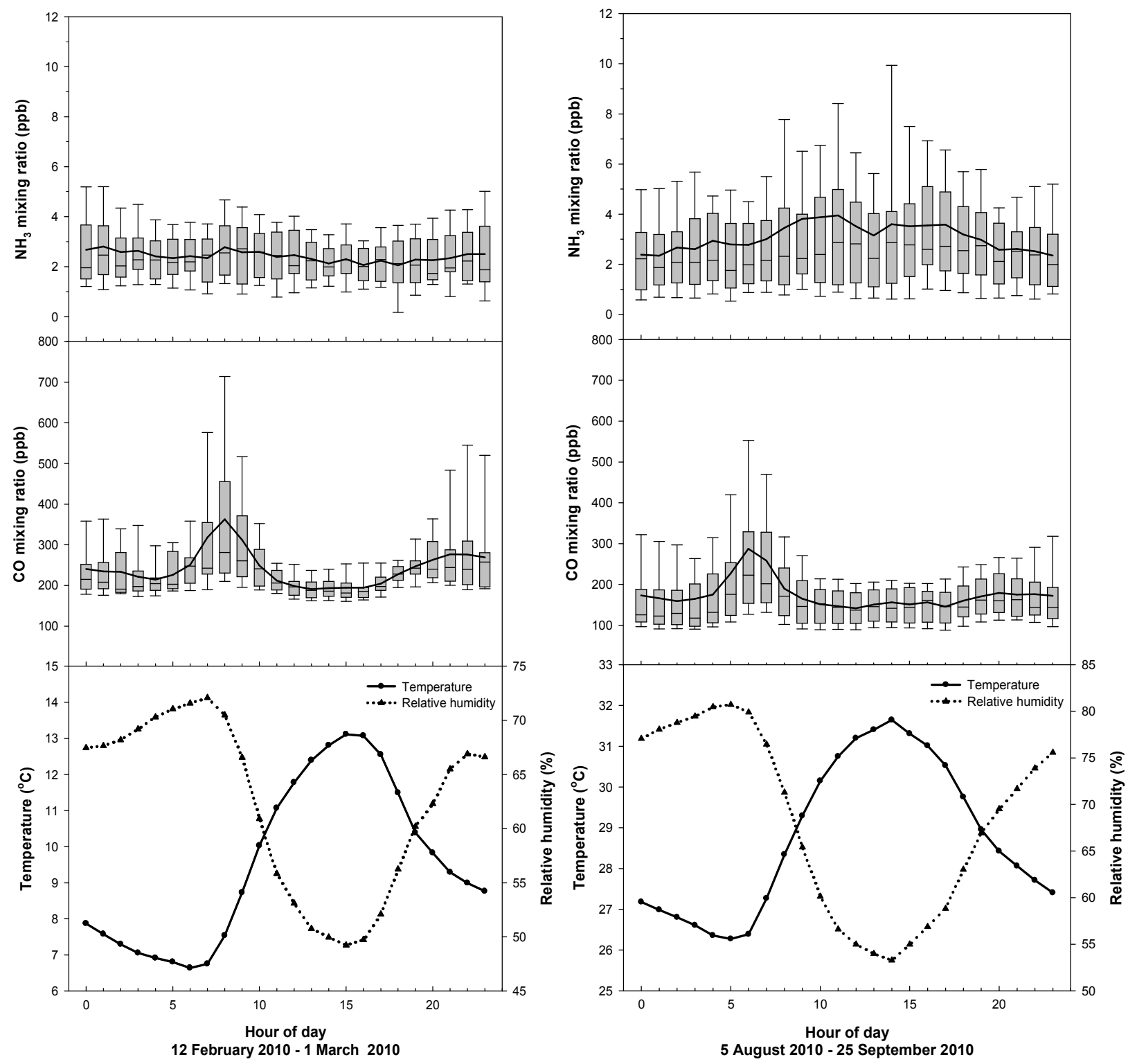

Fig. 3. Diurnal profiles of $\mathrm{NH}_{3}$ and $\mathrm{CO}$ mixing ratios as well as temperature and relative humidity during the two sampling periods. The bottom whisker, box bottom, line inside the box, box top, and top whisker represent the 10th, 25th, 50th, 75th, and 90th percentiles of the data, and the continuous lines represent mean values, respectively. (a) 12 February-1 March 2010; (b) 5 August-25 September 2010.

Ianniello et al., 2010; Saylor et al., 2010). For example, natural emissions of $\mathrm{NH}_{3}$ (e.g. vegetation and volatilization of animal waste) increase in strength with increasing temperature. In addition, colder conditions favor particulate ammonium formation while higher temperatures in summer shift the thermodynamic equilibrium towards the gas phase, consequently elevating gaseous $\mathrm{NH}_{3}$ levels.

\subsection{Diurnal variation}

Auxiliary data collected atop the Moody Tower were incorporated into data analyses to assist in the $\mathrm{NH}_{3}$ source identi- fication in Houston. For example, primary pollutants such as $\mathrm{NO}_{\mathrm{x}}$ and $\mathrm{CO}$ emitted from tailpipes are usually used as indicators of vehicular emissions. Figure 3 shows a set of box plots that indicate the diurnal profiles of $\mathrm{NH}_{3}$ and $\mathrm{CO}$ mixing ratios as well as temperature and relative humidity during the two sampling periods. Generally, $\mathrm{NH}_{3}$ mixing ratios increased in the morning and peaked at 08:00 CST in winter and at 11:00 CST in summer, respectively, while the CO peak also was observed during morning rush hours as a consequence of large vehicular emissions in combination with the lingering effect of a shallow nocturnal boundary layer. Note that the CO peak appeared two hours later in winter 


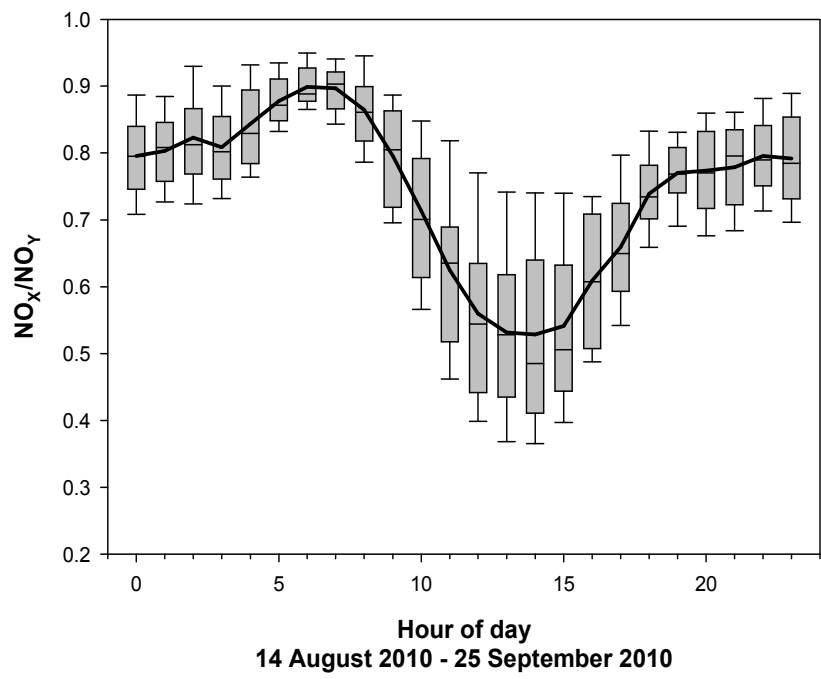

Fig. 4. Diurnal profiles of the ratio of $\mathrm{NO}_{\mathrm{x}}$ to $\mathrm{NO}_{\mathrm{y}}$ during the summer of 2010 (5 August-25 September).

(08:00 CST) than in summer (06:00 CST), which may be attributed to seasonal traffic conditions resulting from different human activity patterns. Then the mixing ratio of $\mathrm{NH}_{3}$ quickly decreased and reached the minimum value around mid-day, suggesting that some removal and/or dilution mechanisms play critical roles at that time. Recurring increases in $\mathrm{NH}_{3}$ were observed in the early afternoon; the bimodal trend was more pronounced in summer compared to winter. A second enhancement in $\mathrm{CO}$ mixing ratios can be observed with increasing traffic between 17:00-21:00 CST, followed by a decrease at night due to the decrease of sources. The mixing ratio of $\mathrm{NH}_{3}$ remained relatively depleted at night in winter, while a gradually slow increase in $\mathrm{NH}_{3}$ mixing ratios during nighttime in summer was observed. Replicate measurements were conducted in the winter of 2011 (1 February-10 March) and indicate similar wintertime dynamics of $\mathrm{NH}_{3}$.

As shown in Fig. 4, in summer, the ratio of $\mathrm{NO}_{\mathrm{x}}$ to $\mathrm{NO}_{\mathrm{y}}$, an indicator of the photochemical age of air masses or plumes, reached the minimum value at mid-day (13:00 CST) when the decrease in $\mathrm{NH}_{3}$ mixing ratios also occurred. Given the strongest solar radiation in the middle of the day, some sinks related to the intense photochemical processes is a likely explanation for the noticeable decrease at mid-day.

In summer, $\mathrm{NH}_{3}$ mixing ratios increased not only after sunrise but also between midnight and 06:00 CST. However, the magnitude was much smaller, and the rate was much slower compared to the sharp morning increase. Small amounts of emissions (from a relatively small number of sources) into a shallow nocturnal boundary layer could lead to the increasing mixing ratios.

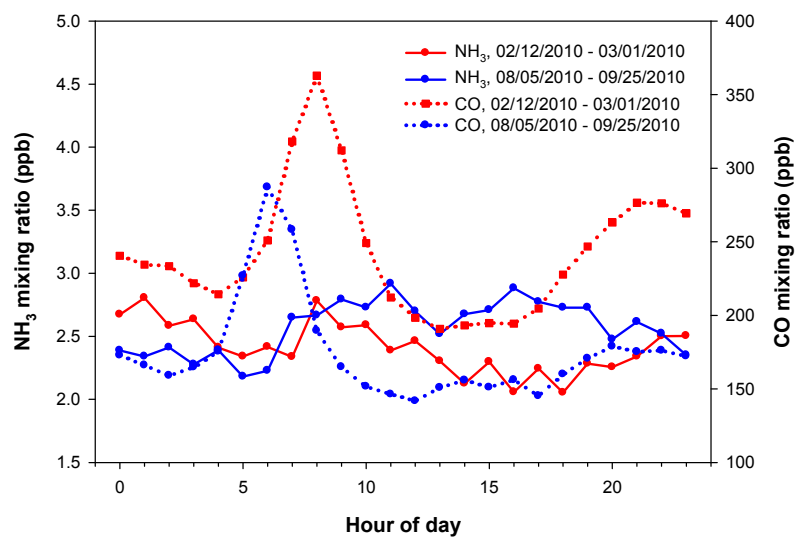

Fig. 5. Diurnal hourly average $\mathrm{NH}_{3}$ and $\mathrm{CO}$ mixing ratios during the two sampling campaigns in Houston. As discussed in the text, outlier plumes are removed from this analysis in summer.

\subsection{Correlation between $\mathrm{NH}_{3}$ and vehicular emissions}

Since the introduction of three-way catalytic converters, motor vehicles have become significant contributors to elevated $\mathrm{NH}_{3}$ levels in urban areas. When $\mathrm{NO}_{\mathrm{x}}$ is over-reduced inside the converters, post-catalyst $\mathrm{NH}_{3}$ will be formed. Many studies observed this phenomenon. In Los Angeles, Fraser and Cass (1998) estimated an average $\mathrm{NH}_{3}$ emission rate of $61 \mathrm{mg}$ per $\mathrm{km}$ driven for a vehicle fleet driving under rich air-fuel conditions in a roadway tunnel. In San Francisco, Kean and Harley (2000) reported reductions in $\mathrm{NO}_{\mathrm{x}}$ and $\mathrm{CO}$ emissions but large increases in $\mathrm{NH}_{3}$ concentrations (with an emission factor of $475 \mathrm{mg}$ per liter of fuel consumed) after catalytic converters were installed widely on automobiles. In Rome, Perrino et al. (2002) found a strong correlation between $\mathrm{NH}_{3}$ and $\mathrm{CO}$, and at traffic sites, $\mathrm{NH}_{3}$ concentrations were five times larger than at background sites. In New York City, Li et al. (2006) conducted $\mathrm{NH}_{3}$ measurements at a school. Many $\mathrm{NH}_{3}$ spikes were observed during rush hour periods. In addition, increased $\mathrm{NH}_{3}$ concentrations on school days compared to non-school days were associated with increased traffic volumes.

In order to examine the relationship between $\mathrm{NH}_{3}$ and $\mathrm{CO}$ in this study better, Fig. 5 summarizes hourly average $\mathrm{NH}_{3}$ and $\mathrm{CO}$ data during the two sampling periods. To eliminate potential interferences, we removed the "outlier plumes" leading to elevated $\mathrm{NH}_{3}$ levels from sources other than traffic emissions for Figs. 5 and 6. The mixing ratios of $\mathrm{NH}_{3}$ larger than 95th percentile of the data are considered as the "outlier plumes" for the analysis in this study. The determination of non-traffic sources is based on the analysis of other auxiliary data and meteorological parameters. Detailed descriptions can be found in the following sections. Generally, these plumes occurred during the daytime on weekdays when the sampling site was downwind of specific emission sources. Resultant episodes of high $\mathrm{NH}_{3}$ mixing ratios were very large compared to other periods of the measurements. 


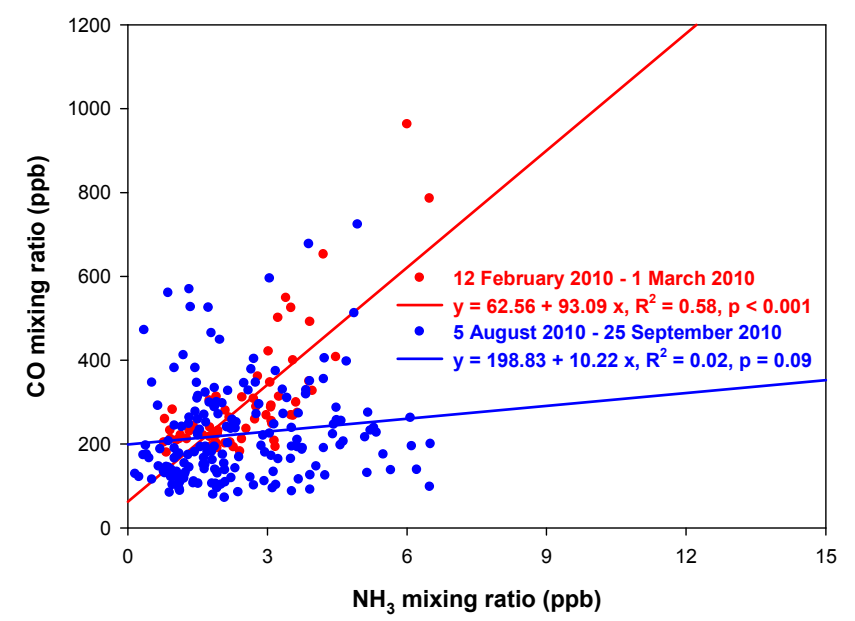

Fig. 6. Scatter plot of $\mathrm{NH}_{3}$ versus $\mathrm{CO}$ for rush hours (06:0010:00 CST) during the two sampling periods. As discussed in the text, outlier plumes are removed from this analysis in summer.

As shown in Fig. 5, winter morning enhancements in $\mathrm{NH}_{3}$ were coincident with enhanced $\mathrm{CO}$, indicating that motor vehicles are likely a major emission source of $\mathrm{NH}_{3}$ in Houston during this period; no such concurrent increases were observed in summer. This phenomenon is further illustrated by the linear regressions given in Fig. 6 that show a moderate correlation $\left(R^{2}=0.58, p<0.001\right)$ between $\mathrm{NH}_{3}$ and $\mathrm{CO}$ during morning rush hours (06:00-10:00 CST) in winter but no relationship $\left(R^{2}=0.02, p=0.09\right)$ in summer. Figure 7 shows the diurnal profiles of $\mathrm{NO}_{\mathrm{x}}$ and $\mathrm{NO}_{\mathrm{y}}$ mixing ratios in summer that exhibit trends similar to that for $\mathrm{CO}$, with a significant increase during morning rush hours and a second small peak appearing in the late afternoon. The temporal gap between the $\mathrm{NH}_{3}$ peak and $\mathrm{NO}_{\mathrm{x}}$ and $\mathrm{NO}_{\mathrm{y}}$ peaks in the morning further confirms that vehicular emissions were not major sources of $\mathrm{NH}_{3}$ in summer.

It is hypothesized that this seasonal difference is related to changes in vehicular catalytic converter performance as a function of ambient temperature. In winter, engines more frequently run under high-load conditions in order to reach and maintain the optimal operating temperature. This potentially induces fuel-rich combustion which favors reducing processes on the catalyst surface. As a result, more $\mathrm{NH}_{3}$ is produced in vehicle exhaust (Shelef and McCabe, 2000; Heck and Farrauto, 2001; Defoort et al., 2004; Heeb et al., 2006). Additional emission sources of $\mathrm{NH}_{3}$ present in summer also may obscure the correlation between $\mathrm{NH}_{3}$ and $\mathrm{CO}$.

Another explanation for the inconsistent $\mathrm{NH}_{3}-\mathrm{CO}$ relationship between seasons is that air masses transported from different wind directions to the Moody Tower have distinct characteristics. As shown in Fig. 8a, the wind mainly blew from the SE (William P. Hobby Airport and highways) during morning rush hours in winter, while the wind mainly blew from the NE (HSC) during morning rush hours in sum-

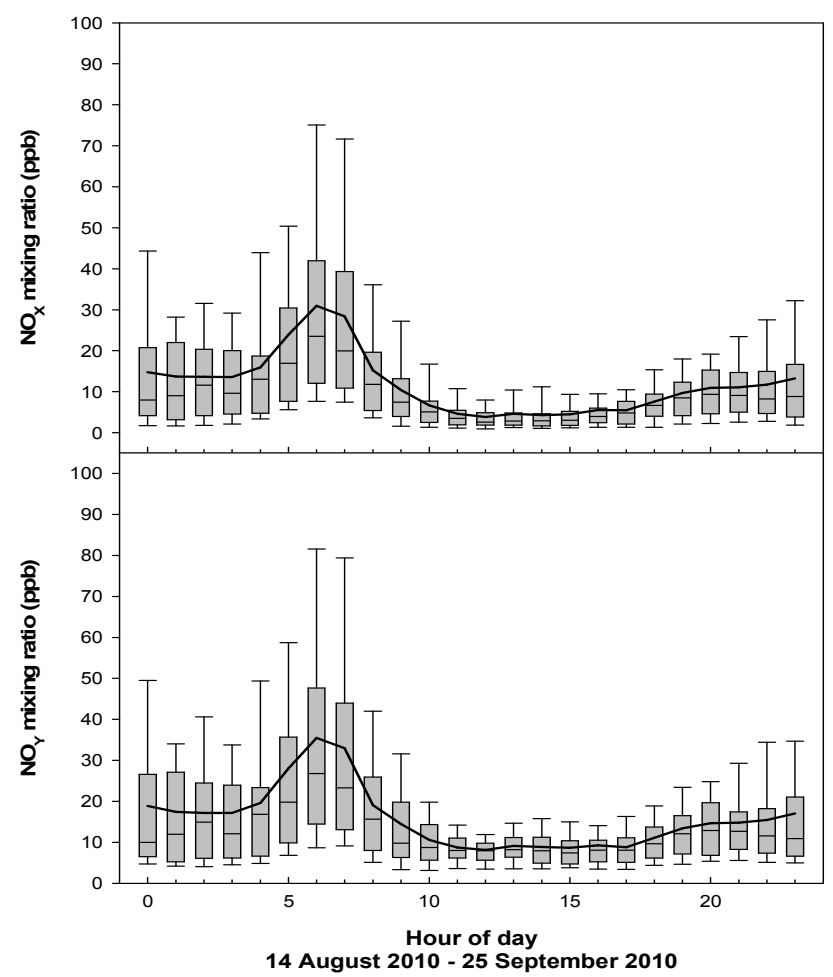

Fig. 7. Diurnal profiles of $\mathrm{NO}_{\mathrm{x}}$ and $\mathrm{NO}_{\mathrm{y}}$ mixing ratios during the summer of 2010 at the Moody Tower.

mer. It is assumed that air transported from the SE contains more primary combustion species than air transported from the NE despite the highly industrial nature of the HSC. The prevailing wind direction shifted at the sampling site during other time periods of the day.

Morning increases in $\mathrm{NH}_{3}$ mixing ratios were notable throughout the measurement periods. For example, the morning increase in winter appeared to be associated with motor vehicular activities. However, many factors may be responsible for this behavior. It can be seen in Fig. 3 that there were significant changes in temperature and relative humidity beginning at 06:00 CST, when $\mathrm{NH}_{3}$ mixing ratios also began to increase quickly. It is possible that the evaporation of dew associated with increasing temperature releases $\mathrm{NH}_{3}$ into the atmosphere, especially in summer when the early morning relative humidity was higher compared to winter. Ellis et al. (2011) also pointed out that the natural emissions of $\mathrm{NH}_{3}$ from vegetation and soil through photosynthetic processes might be important contributors to a morning increase. In this work, $\mathrm{PM}$ sulfate $\left(\mathrm{SO}_{4}^{2-}\right)$ and nitrate $\left(\mathrm{NO}_{3}^{-}\right)$data are currently unavailable, so the effect of gas-particle partitioning on gaseous $\mathrm{NH}_{3}$ concentrations cannot be clarified. Figure 9 illustrates the diurnal profile of the PBL height in summer. It can be seen that the PBL height remained low and did not begin to break up until 07:00 CST. Therefore, vertical mixing of $\mathrm{NH}_{3}$ from the residual layer is eliminated as a potential major contributor to the morning increase. 

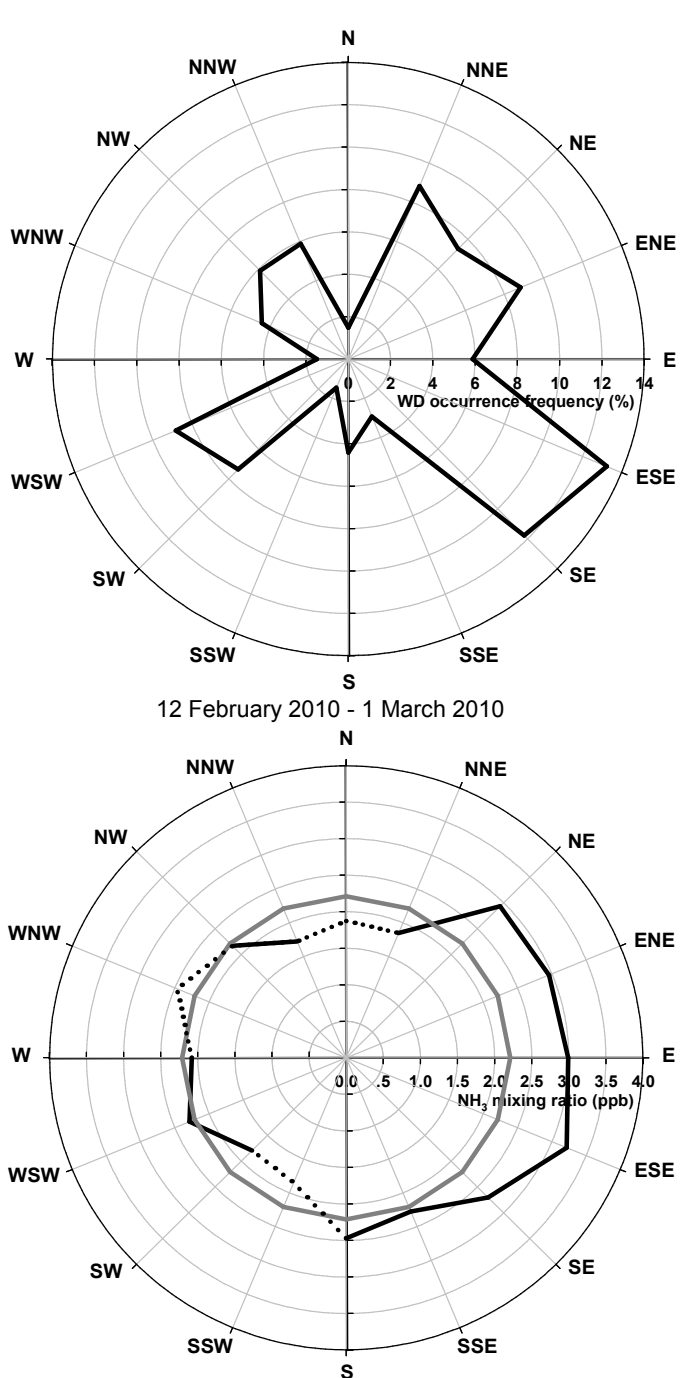

12 February 2010 - 1 March 2010

- Median mixing ratio from wind directions with frequency $>3 \%$ Median mixing ratio over the entire sampling period ..... Median mixing ratio from wind directions with frequency $<3 \%$
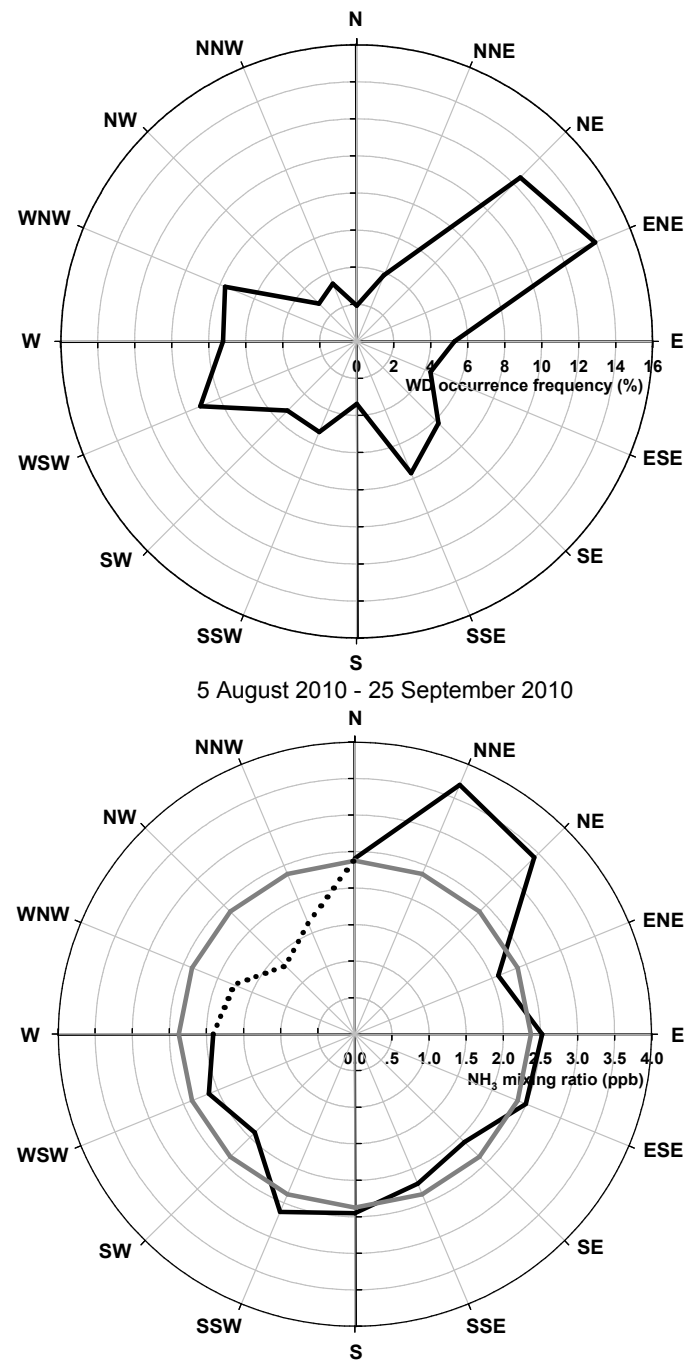

5 August 2010 - 25 September 2010

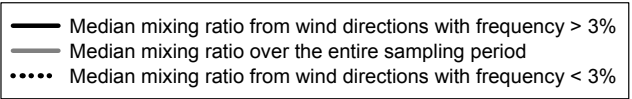

Fig. 8. (a) Wind direction (WD) distributions during morning rush hours (06:00-10:00 CST) and (b) the dependence of $\mathrm{NH}_{3}$ mixing ratios on wind direction.

\subsection{Source identification}

In order to evaluate the effect of local or regional sources on atmospheric $\mathrm{NH}_{3}$ levels, Fig. $8 \mathrm{~b}$ illustrates the dependence of $\mathrm{NH}_{3}$ mixing ratios on wind direction for the duration of both sampling periods. The wind rose is divided into 16 sectors, and the data correspondingly are grouped into $22.5^{\circ}$ intervals. The polar plots present the median mixing ratio in each bin, showing increased $\mathrm{NH}_{3}$ levels were often associated with the wind blowing from NE or $\mathrm{E}$ in the direction of the HSC where numerous petrochemical refineries are densely located. The estimated $\mathrm{NH}_{3}$ emissions in that area were approximately $0.25 \mathrm{t}$ per hour during the 2006 Texas Air Quality Study (Mellqvist et al., 2007). Large $\mathrm{NH}_{3}$ con- centrations near industrial facilities were also noted by some other studies, including that of Hsieh and Chen (2010) who measured $\mathrm{NH}_{3}$ levels elevated compared to ambient background levels by a factor of $50-150$ in three heavily industrialized parks in south Taiwan.

Large weekday-weekend differences in $\mathrm{NH}_{3}$ and $\mathrm{CO}$ mixing ratios were observed throughout the measurements as shown in Fig. 10. Enhanced $\mathrm{NH}_{3}$ values on weekdays compared to weekends are probably due to increased industrial activity between Monday and Friday when most of the "outlier plumes" occurred. Brooks et al. (2010) concluded that the HSC is a major emission source of mercury species in Houston, and concentrations measured atop the Moody Tower were much higher on weekdays than weekends. CO 


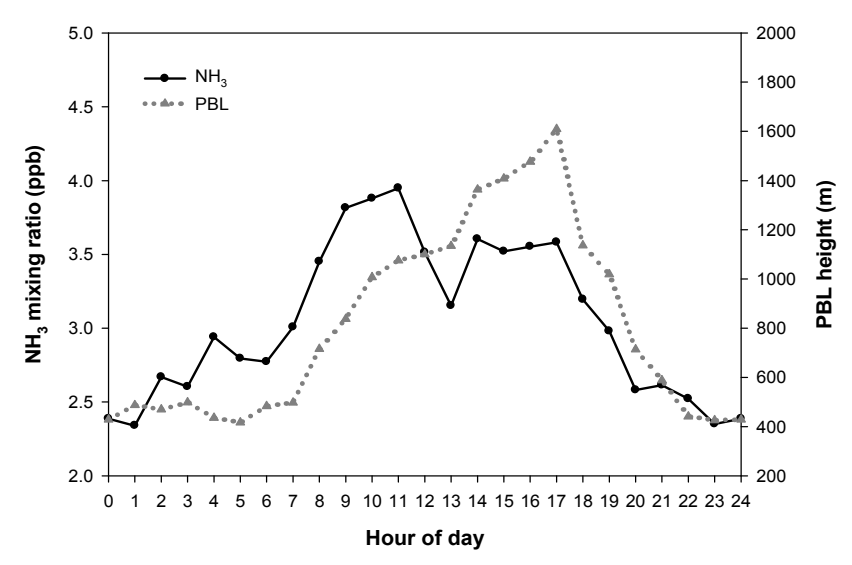

Fig. 9. $\mathrm{NH}_{3}$ mixing ratios and $\mathrm{PBL}$ heights during the summer of 2010 .

values displayed a similar behavior with the substantially smaller morning rush hour maximum on weekends with decreased traffic volumes. It is also noted that $\mathrm{CO}$ mixing ratios between midnight and 04:00 CST were higher on weekends than weekdays in summer. This may be attributed to vehicular emissions related to some late night human activities in warm seasons.

The diurnal profile of $\mathrm{SO}_{2}$ mixing ratios in summer is illustrated in Fig. 11 and exhibits a morning increase starting from 05:00 CST and peaking at 09:00 CST, followed by a slight increase in the early afternoon and a decrease for the remainder of the day. In August, some rapid $\mathrm{NH}_{3}$ increases were found to be synchronous with similar $\mathrm{SO}_{2}$ increases when the wind blew from the SW (as verified by both wind direction and Hybrid Single-Particle Lagrangian Integrated Trajectory (HYSPLIT, Draxler and Rolph, 2011) backward trajectory analysis), the direction of the second largest coalfired electricity generating station in the US. Since 2000, this plant has employed the selective catalytic reduction (SCR) technique to control $\mathrm{NO}_{\mathrm{x}}$ emissions (Peischl et al., 2010); in $\mathrm{SCR}$, a large amount of $\mathrm{NH}_{3}$ is used as a reducing reagent. Occasional $\mathrm{NH}_{3}$ slips into the atmosphere during SCR processes may contribute to the coincident enhancements in $\mathrm{NH}_{3}$ and $\mathrm{SO}_{2}$ mixing ratios, suggesting the co-emission from a point source. Interestingly, Nowak et al. (2010) did not observe similar spikes of $\mathrm{NH}_{3}$ in the plume from this power plant during the summer of 2006.

In addition, the EPA Positive Matrix Factorization (PMF) 3.0 (Paatero and Tapper, 1994; Paatero, 1997) model was used to conduct source attribution. Results clearly show that in summer the HSC $(62.5 \%)$ is the largest source category followed by power plants $(35.5 \%)$ and automobiles $(2 \%)$. Because volatile organic compound data used in the model were collected at a local ambient air quality monitoring station in the HSC area operated by the Texas Commission on Environmental Quality instead of at the Moody Tower due to the current unavailability of data from co-located instruments, these results must be viewed as preliminary.

\subsection{Remarkable events}

There is a considerable degree of variability in atmospheric $\mathrm{NH}_{3}$ mixing ratios in the Houston atmosphere. Some unexpected events were observed during summertime measurements, indicating that local or regional sources present in Greater Houston affected the observational results at the Moody Tower. For example, the laser sensor recorded a significant and lasting increase in $\mathrm{NH}_{3}$ mixing ratios $(\sim 21 \mathrm{ppb})$ on 14 August 2010, when a major accident occurred during the same time period on the Gulf Freeway (Interstate 45) in Houston, only two miles from the sampling site. The elevated concentration levels are assumed to be associated with $\mathrm{NH}_{3}$ generation from a chemical fire resulting from the collision of two 18-wheeled tankers/cargo vehicles, one carrying fertilizer (trimethylammonium) and pesticide (dimethylamine). To our knowledge, this is the first time that an accidental release of $\mathrm{NH}_{3}$ has been detected remotely and in realtime by an optical sensor. Similar observations were reported by Nowak et al. (2010) who found elevated $\mathrm{NH}_{3}$ mixing ratios up to $80 \mathrm{ppb}$ in a plume due to an industrial accident in Baytown, along the HSC.

Another episode of elevated $\mathrm{NH}_{3}$ levels ( $22 \mathrm{ppb}$ ) occurred on 7 September 2010, which might be related to the transport of emissions from the Gulf of Mexico during Hurricane Hermine. The storm led to strong wind ( $\sim 20$ miles per hour) blowing from the SE, and HYSPLIT backward trajectories showed that before arriving at the Moody Tower, air masses passed by some industry in the Texas City area, approximately 40 miles SE of Downtown Houston. The fast air movement decreased the probability of physical and chemical losses in the plumes prior to their arrival in Houston. Some previous studies have shown increased concentrations of halogen containing compounds in the atmosphere associated with emissions from the ocean during storm/hurricane activities (Varner et al., 2008); enhanced emissions from the Gulf cannot be eliminated in this case.

The third notable event occurred on 17 September 2010 when the sampling site was downwind of the HSC in the morning. The $\mathrm{NH}_{3}$ levels were elevated to $\sim 27 \mathrm{ppb}$ while no concurrent enhancements in mixing ratios of other air pollutants were observed. However, specific $\mathrm{NH}_{3}$ sources in that heavily industrialized area cannot be identified on the basis of the data presented here.

\section{Conclusions}

In this work we demonstrated atmospheric $\mathrm{NH}_{3}$ measurement results using a 10.4- $\mu \mathrm{m}$ EC-QCL-based sensor employing conventional photo-acoustic spectroscopy with a minimum detection limit below $1 \mathrm{ppb}$. Time resolved $(5 \mathrm{~s})$ measurements of atmospheric $\mathrm{NH}_{3}$ were conducted atop the Moody Tower during two sampling periods in 2010; data were averaged to five minutes. $\mathrm{NH}_{3}$ mixing ratios ranged 

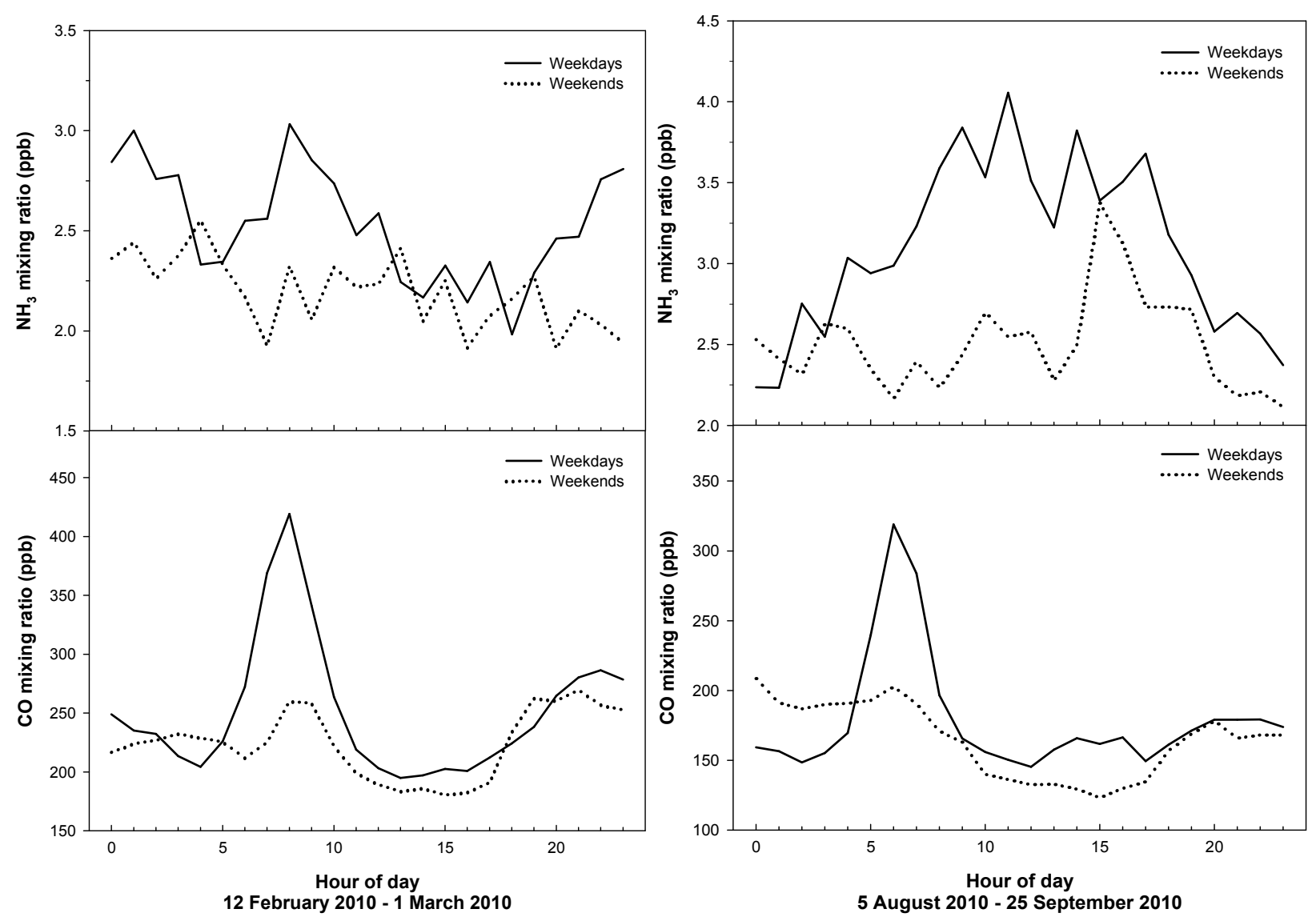

Fig. 10. Comparisons of hourly-averaged $\mathrm{NH}_{3}$ and $\mathrm{CO}$ mixing ratios between weekdays and weekends during the two sampling periods.

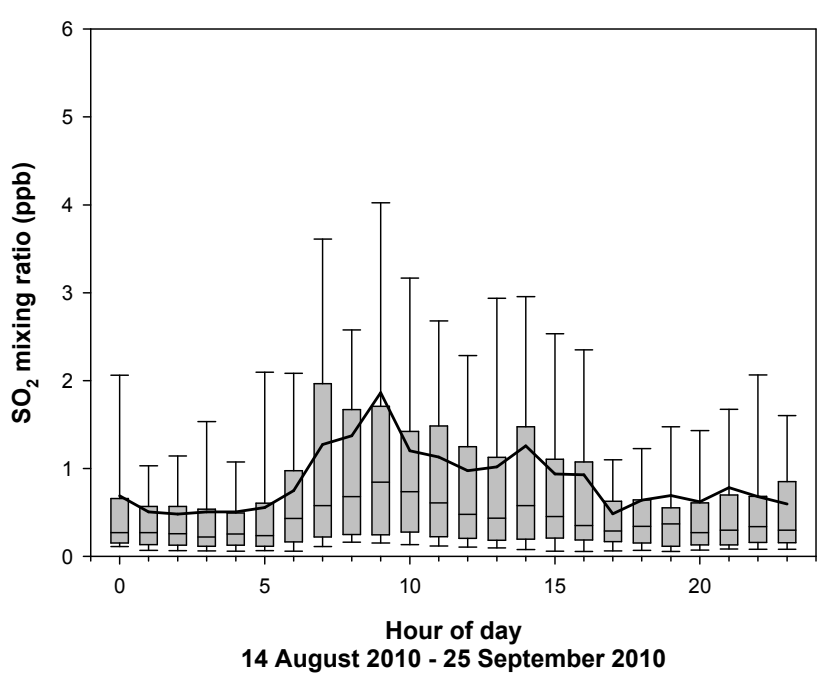

Fig. 11. The diurnal profile of $\mathrm{SO}_{2}$ mixing ratios during the summer of 2010 .

from 0.1 to $8.7 \mathrm{ppb}$ with a mean of $2.4 \pm 1.2 \mathrm{ppb}$ in winter and ranged from 0.2 to $27.1 \mathrm{ppb}$ with a mean of $3.1 \pm 2.9 \mathrm{ppb}$ in summer. The results showed apparent seasonal variations, with elevated levels in summer compared to winter. Vehicular emissions were found to be major contributors to the morning rise in the diurnal profile of $\mathrm{NH}_{3}$ mixing ratios in winter. There was no correlation between $\mathrm{NH}_{3}$ and primary combustion pollutants such as $\mathrm{CO}, \mathrm{NO}_{\mathrm{x}}$, and $\mathrm{NO}_{\mathrm{y}}$ during morning rush hours in summer, which might be attributed to changes in catalytic converter performance as a function of ambient temperature and influences by some other local or regional sources of $\mathrm{NH}_{3}$. There was a large amount of variability in atmospheric $\mathrm{NH}_{3}$ mixing ratios observed at our sampling site, particularly in summer. Notable spikes were associated with transport from a coal-fired power plant, a chemical fire on an adjacent highway as a result of the crash of a tanker carrying agricultural chemicals, transport from the heavily industrialized HSC, transport from the Gulf of Mexico during Hurricane Hermine, and other potential ambient sources. The large weekday-weekend differences in $\mathrm{NH}_{3}$ mixing ratios are likely due to more industrial activities between Monday and Friday, presumably in the HSC area, which has been shown to be a predominant emission source of $\mathrm{NH}_{3}$. Unfortunately, source attribution is confounded by factors such as boundary layer dynamics, meteorology, and the lack of sufficient emission inventory data. In the future, 
particle composition data and $\mathrm{HNO}_{3}$ data will be used to better characterize the importance of $\mathrm{NH}_{3}$ with respect to $\mathrm{PM}$ formation in Houston.

Acknowledgements. This study is supported by the MidInfraRed Technologies for Health and the Environment (MIRTHE) Center and National Science Foundation (NSF) under grant No. EEC-0540832. The authors gratefully acknowledge the US EPA for supplying the PMF 3.0 model (http://www.epa.gov/heasd/products/pmf/pmf.html) and NOAA Air Resources Laboratory (ARL) for the provision of the HYSPLIT transport and dispersion model and READY website (http://www.arl.noaa.gov/ready.php) used in this publication. The authors would like to thank Barbara Schmeitz and Christine Haman for their help in auxiliary data preparation. Sincere thanks are also conveyed to J. Schwab and anonymous reviewers for their valuable comments and constructive suggestions on the manuscript.

Edited by: A. Pszenny

\section{References}

Aneja, V. P., Chauhan, J. P., and Walker, J. T.: Characterization of atmospheric ammonia emissions from swine waste storage and treatment lagoons, J. Geophy. Res.-Atmos., 105, D13302, doi:10.1029/2000JD900066, 2000.

Aneja, V. P., Bunton, B., Walker, J. T., and Malik, B. P.: Measurement and analysis of atmospheric ammonia emissions from anaerobic lagoons, Atmos. Environ., 35, 1949-1958, 2001.

Bari, A., Ferraro, V., Wilson, L. R., Luttinger, D., and Husain, L.: Measurements of gaseous $\mathrm{HONO}, \mathrm{HNO}_{3}, \mathrm{SO}_{2}, \mathrm{HCL}, \mathrm{NH}_{3}$, particulate sulfate and $\mathrm{PM}_{2.5}$ in New York City, Atmos. Environ., 37, 2825-2835, 2003.

Brook, J. R., Wiebe, A. H., Woodhouse, S. A., Audette, C. V., Dann, T. F., Callaghan, S., Piechowski, M., Dabek-Zlotorzynska, E., and Dloughy, J. F.: Temporal and spatial relationships in fine particle strong acidity, sulphate, $\mathrm{PM}_{10}$, and $\mathrm{PM}_{2.5}$ across multiple Canadian locations, Atmos. Environ., 31, 4223-4236, 1997.

Brooks, S., Luke, W., Cohen, M., Kelly, P., Lefer, B., and Rappenglück, B.: Mercury species measured atop the Moody Tower TRAMP site, Houston, Texas, Atmos. Environ., 44, 4045-4055, 2010.

Burkhardt, J., Sutton, M. A., Milford, C., Storeton-West, R. L., and Fowler, D.: Ammonia concentrations at a site in southern Scotland from $2 \mathrm{yr}$ of continuous measurements, Atmos. Environ., 32, 325-331, 1998.

Clarisse, L., Clerbaux, C., Dentener, F., Hurtmans, D., and Coheur, P.: Global ammonia distribution derived from infrared satellite observations, Nat. Geosci., 2, 479-483, doi:10.1038/ngeo551, 2009.

Clarisse, L., Shephard, M. W., Dentener, F., Hurtmans, D., CadyPereira, K., Karagulian, F., Van Damme, M., Clerbaux, C., and Coheur, P.: Satellite monitoring of ammonia: A case study of the San Joaquin Valley, J. Geophys. Res.-Atmos., 115, D13302, doi:10.1029/2009JD013291, 2010.

Day, B. M., Rappenglück, B., Clements, C. B., Tucker, S. C., and Brewer, W. A.: Nocturnal boundary layer characteristics and land breeze development in Houston, Texas during TexAQS II, Atmos. Environ., 44, 4014-4023, 2010.
Defoort, M., Olsen, D., and Willson, B.: The effect of air-fuel ratio control strategies on nitrogen compound formation in three-way catalysts, Int. J. Engine Res., 5, 115-122, 2004.

Draxler, R. R. and Rolph, G. D.: HYSPLIT (HYbrid Single-Particle Lagrangian Integrated Trajectory) Model access via NOAA ARL READY Website (http://ready.arl.noaa.gov/HYSPLIT.php, last access: 14 January 2011), NOAA Air Resources Laboratory, Silver Spring, MD, 2011.

Edgerton, E. S., Saylor, R. D., Hartsell, B. E., Jansen, J. J., and Hansen, D. A.: Ammonia and ammonium measurements from the southeastern United States, Atmos. Environ., 41, 3339-3351, 2007.

Ellis, R. A., Murphy, J. G., Markovic, M. Z., VandenBoer, T. C., Makar, P. A., Brook, J., and Mihele, C.: The influence of gasparticle partitioning and surface-atmosphere exchange on ammonia during BAQS-Met, Atmos. Chem. Phys., 11, 133-145, doi:10.5194/acp-11-133-2011, 2011.

Erisman, J. W., Otjes, R., Hensen, A., Jongejan, P., van den Bulk, P., Khlystov, A., Möls, H., and Slanina, S.: Instrument development and application in studies and monitoring of ambient ammonia, Atmos. Environ., 35, 1913-1922, 2001.

Fehsenfeld, F. C., Huey, L. G., Leibrock, E., Dissly, R., Williams, E., Ryerson, T. B., Norton, R., Sueper, D. T., and Hartsell, B.: Results from an informal intercomparison of ammonia measurements techniques, J. Geophys. Res.-Atmos., 107, D24, doi:10.1029/2001JD001327, 2002.

Ferm, M., Marcinkowski, T., Kieronczyk, M., and Pietrzak, S.: Measurements of ammonia emissions from manure storing and spreading stages in Polish commercial farms, Atmos. Environ., 39, 7106-7113, 2005.

Fraser, M. P. and Cass, G. R.: Detection of excess ammonia emissions from in-use vehicles and the implications for fine particle control, Environ. Sci. Tech., 32, 1053-1057, 1998.

Heck, R. M. and Farrauto, R. J.: Automobile exhaust catalysts, Appl. Catal. A: General, 221, 443-457, 2001.

Heeb, N. V., Forss, A., Brühlmann, S., Lüscher, R., Saxer, C. J., and Hug, P.: Three-way catalyst-induced formation of ammonia - velocity- and acceleration-dependent emission factors, Atmos. Environ., 40, 5986-5997, 2006.

Hoek, G., Mennen, M. G., Allen, G. A., Hofschreuder, P., and Van Der Meulen, T.: Concentrations of acidic air pollutants in the Netherlands, Atmos. Environ., 30, 3141-3150, 1996.

Hsieh, L. T. and Chen, T. C.: Characteristics of ambient ammonia levels measured in three different industrial parks in southern Taiwan, Aerosol Air Qual. Res., 10, 596-608, 2010.

Ianniello, A., Spataro, F., Esposito, G., Allegrini, I., Rantica, E., Ancora, M. P., Hu, M., and Zhu, T.: Occurrence of gas phase ammonia in the area of Beijing (China), Atmos. Chem. Phys., 10, 9487-9503, doi:10.5194/acp-10-9487-2010, 2010.

Kawashima, S. and Yonemura, S.: Measuring ammonia concentration over a grassland near livestock facilities using a semiconductor ammonia sensor, Atmos. Environ., 35, 3831-3839, 2001.

Kean, A. J. and Harley, R. A.: On-road measurement of ammonia and other motor vehicle exhaust emissions, Environ. Sci. Tech., 34, 3535-3539, 2000.

Kean, A. J., Littlejohn, D., Ban-Weiss, G. A., Harley, R. A., Kirchstetter, T. W., and Lunden, M. M.: Trends in on-road vehicle emissions of ammonia, Atmos. Environ., 43, 1565-1570, 2009.

Lee, H. S., Kang, C. M., Kang, B. W., and Kim, H. K.: Seasonal 
variations of acidic air pollutants in Seoul, South Korea, Atmos. Environ., 33, 3143-3152, 1999.

Lefer, B. and Rappenglück, B.: The TexAQS-II radical and aerosol measurement project (TRAMP), Atmos. Environ., 44, 39974004, 2010.

Lefer, B., Rappenglück, B., Flynn, J., and Haman, C.: Photochemical and meteorological relationships during the Texas-II Radical and Aerosol Measurement Project (TRAMP), Atmos. Environ., 44, 4005-4013, 2010.

Li, Y., Schwab, J. J., and Demerjian, K. L.: Measurements of ambient ammonia using a tunable diode laser absorption spectrometer: Characteristics of ambient ammonia emissions in an urban area of New York City, J. Geophys. Res., 111, D10S02, doi:10.1029/2005JD006275, 2006.

Lin, Y. C., Cheng, M. T., Ting, W. Y., and Yeh, C. R.: Characteristics of gaseous $\mathrm{HNO}_{2}, \mathrm{HNO}_{3}, \mathrm{NH}_{3}$, and particulate ammonium nitrate in an urban city of Central Taiwan, Atmos. Environ., 40, 4725-4733, 2006.

Luke, W. T., Kelley, P., Lefer, B., Flynn, J., Rappenglück, B., Leuchner, M., Dibb, J. E., Ziemba, L. D., Anderson, C. H., and Buhr, M.: Measurements of primary trace gases and $\mathrm{NO}_{\mathrm{Y}}$ composition in Houston, Texas, Atmos. Environ., 44, 4068-4080, 2010.

Malm, W. C., Schichtel, B. A., Pitchford, M. L., Ashbaugh, L. L., and Eldred, R. A.: Spatial and monthly trends in speciated fine particle concentration in the United States, J. Geophys. Res.Atmos., 109, D03306, doi:10.1029/2003JD003739, 2004.

Matsumoto, M. and Okita, T.: Long term measurements of atmospheric gaseous and aerosol species using an annular denuder system in Nara, Japan, Atmos. Environ., 32, 1419-1425, 1998.

McMurry, P. H., Fink, M., Sakurai, H., Stolzenburg, M. R., Mauldin III, R. L., Smith, J., Eisele, F., Moore, K., Sjostedt, S., Tanner, D., Huey, L. G., Nowak, J. B., Edgerton, E., and Voisin, D.: A criterion for new particle formation in the sulfur-rich Atlanta atmosphere, J. Geophys. Res.-Atmos., 110, D22S02, doi:10.1029/2005JD005901, 2005.

Mellqvist, J., Samuelsson, J., and Rivera, C.: Measurements of industrial emissions of $\mathrm{VOC}_{S}, \mathrm{NH}_{3}, \mathrm{NO}_{2}$ and $\mathrm{SO}_{2}$ in Texas using the Solar Occultation Flux method and mobile DOAS, Final Report, HARC Project H-53, 2007.

Mount, G. H., Rumburg, B., Havig, J., Lamb, B., Westberg, H., Yonge, D., Johnson, K., and Kincaid, R.: Measurement of atmospheric ammonia at a dairy using differential optical absorption spectroscopy in the mid-ultraviolet, Atmos. Environ. 36, 1799 1810, 2002.

Nowak, J. B., Huey, L. G., Russell, A. G., Tian, D., Neuman, J. A., Orsini, D., Sjostedt, S. J., Sullivan, A. P., Tanner, D. J., Webber, R. J., Nenes, A., Edgerton, E., and Fehsenfeld, F. C.: Analysis of urban gas phase ammonia measurements from the 2002 Atlanta Aerosol Nucleation and Real-Time Characterization Experiment (ANARChE), J. Geophys. Res.-Atmos., 111, D17308, doi:10.1029/2006JD007113, 2006.

Nowak, J. B., Neuman, J. A., Kozai, K., Huey, L. G., Tanner, D. J., Holloway, J. S., Ryerson, T. B., Frost, G. J., McKeen, S. A., and Fehsenfeld, F. C.: A chemical ionization mass spectrometry technique for airborne measurements of ammonia, J. Geophys. Res.-Atmos., 112, D10S02, doi:10.1029/2006JD007589, 2007.

Nowak, J. B., Neuman, J. A., Bahreini, R., Brock, C. A., Middlebrook, A. M., Wollny, A. G., Holloway, J. S., Peis- chl, J., Ryerson, T. B., and Fehsenfeld, F. C.: Airborne observations of ammonia and ammonium nitrate formation over Houston, TX, J. Geophys. Res.-Atmos., 115, D22304, doi:10.1029/2010JD014195, 2010.

Olszyna, K. J., Bairai, S. T., and Tanner, R. L.: Effect of ambient $\mathrm{NH}_{3}$ levels on $\mathrm{PM}_{2.5}$ composition in the Great Smoky Mountains National Park, Atmos. Environ., 39, 4593-4606, 2005.

Paatero, P.: Least squares formulation of robust non-negative factor analysis, Chemometr. Intell. Lab. Syst., 37, 23-35, 1997.

Paatero, P. and Tapper, U.: Positive matrix factorization: a nonnegative factor model with optimal utilization of error estimates of data values, Environmetrics, 5, 111-126, 1994.

Pavlovic, R. T., Nopmongcol, U., Kimura, Y., and Allen, D. T.: Ammonia emissions, concentrations and implications for particulate matter formation in Houston, TX, Atmos. Environ., 40, 538-551, 2006.

Peischl, J., Ryerson, T. B., Holloway, J. S., Parrish, D. D., Trainer, M., Frost, G. J., Aikin, K. C., Brown, S. S., Dubé, W. P., Stark, H., and Fehsenfeld, F. C.: A top-down analysis of emissions from selected Texas power plants during TexAQS 2000 and 2006, J. Geophys. Res.-Atmos., 115, D16303, doi:10.1029/2009JD013527, 2010.

Perrino, C., Catrambone, M., Di Menno Di Bucchianico, A., and Allegrini, I.: Gaseous ammonia in the urban area of Rome, Italy and its relationship with traffic emissions, Atmos. Environ., 36, 5385-5394, 2002.

Pogány, A., Mohácsi, Á., Jones, S. K., Nemitz, E., Varga, A., Bozóki, Z., Galbács, Z., Weidinger, T., Horváth, L., and Szabó, G.: Evaluation of a diode laser based photoacoustic instrument combined with preconcentration sampling for measuring surface-atmosphere exchange of ammonia with the aerodynamic gradient method, Atmos. Environ., 44, 1490-1496, 2010.

Pryor, S. C., Barthelmie, R. J., Sørensen, L. L., and Jensen, B.: Ammonia concentrations and fluxes over a forest in the midwestern USA, Atmos. Environ., 35, 5645-5656, 2001.

Robarge, W. P., Walker, J. T., McCulloch, R. B., and Murray, G.: Atmospheric concentrations of ammonia and ammonium at an agricultural site in the southeast United States, Atmos. Environ. 36, 1661-1674, 2002.

Rumburg, B., Mount, G. H., Filipy, J., Lamb, B., Westberg, H., Yonge, D., Kincaid, R., and Johnson, K.: Measurement and modeling of atmospheric flux of ammonia from dairy milking cow housing, Atmos. Environ., 42, 3364-3379, 2008.

Sarwar, G., Corsi, R. L., Kinney, K. A., Banks, J. A., Torres, V. M., and Schmidt, C.: Measurements of ammonia emissions from oak and pine forests and development of a non-industrial ammonia emissions inventory in texas, Atmos. Environ., 39, 7137-7153, 2005.

Saylor, R. D., Edgerton, E. S., Hartsell, B. E., Baumann, K., and Hansen, D. A.: Continuous gaseous and total ammonia measurements from the southeastern aerosol research and characterization (SEARCH) study, Atmos. Environ., 44, 4994-5004, 2010.

Shelef, M. and McCabe, R. W.: Twenty-five years after introduction of automotive catalysts: what next? Catal. Today, 62, 35-50, 2000.

Smith, A. M., Keene, W. C., Maben, J. R., Pszenny, A. A. P., Fischer, E., and Stohl, A.: Ammonia sources, transport, transformation, and deposition in coastal New England during summer, J. Geophys. Res.-Atmos., 112, D10S08, 
doi:10.1029/2006JD007574, 2007.

Song, C. H., Park, M. E., Lee, E. J., Lee, J. H., Lee, B. K., Lee, D. S., Kim, J., Han, J. S., Moon, K. J., and Kondo, Y.: Possible particulate nitrite formation and its atmospheric implications inferred from the observations in Seoul, Korea, Atmos. Environ., 43, 2168-2173, 2009.

Sutton, M. A., Erisman, J. W., Dentener, F., and Möller, D.: Ammonia in the environment: From ancient times to the present, Environ. Pollut., 156, 583-604, 2008.

Varner, R. K., Zhou, Y., Russo, R. S., Wingenter, O. W., Atlas, E., Stroud, C., Mao, H., Talbot, R., and Sive, B. C.: Controls on atmospheric chloroiodomethane $\left(\mathrm{CH}_{2} \mathrm{ClI}\right)$ in marine environments, J. Geophys. Res.-Atmos., 113, D10303, doi:10.1029/2007JD008889, 2008.
Wilson, S. M. and Serre, M. L.: Use of passive samplers to measure atmospheric ammonia levels in a high-density industrial hog farm area of eastern North Carolina, Atmos. Environ., 28, 60746086, 2007.

Yamamoto, N., Nishiura, H., Honjo, T., Ishikawa, Y., and Suzuki, K.: A long-term study of atmospheric ammonia and particulate ammonium concentrations in Yokohama, Japan, Atmos. Environ., 29, 97-103, 1995. 